\title{
Degree of Nurses' Compliance to the Guidelines of Occupational Exposure to Pathogenic Micro-organisms; A Review of Literature
}

\author{
Maria Gamvrouli RN, MHM(c), PhD(c), MHSc', and Maria Kapritsou RN, \\ BSN, MSc, $\mathbf{P h D}^{2}$
}

\begin{abstract}
Biological infectious hazards are the main factors which nursing staff deal with. It is fundamental rule, nurses to apply the guidelines of occupational exposure to pathogenic micro-organisms. The aim of this review was to examine the current literature on the degree of nurses' compliance to the guidelines of occupational according to exposure to pathogenic micro-organisms. A review of literature was conducted on the Medline / PubMed, Cochrane, Scopus, and Google Scholar databases from 2000 to 2018. The keywords used in the bibliography search were, health care professionals, nurses' attitudes, occupational exposure, and safety guidelines. The inclusion criteria were: a) studies that were directly related to the topic, and b) studies in English and Greek language, published in peer-reviewed journals. The search strategy revealed 1287 studies, 1260 excluded. Finally 27 studies were included. Nurses' compliance to the guidelines of occupational exposure to pathogenic microorganisms is described as unsatisfactory, and an emergency situation has been shown to be the major obstacle to follow the guidelines. It is necessary to understand the factors which contribute to nurse's noncompliance. The results show that there is a need to propose measures that will positively affect the nurses' performance.
\end{abstract}

Keywords: Health care professionals; Nurses' attitudes; Occupational exposure; Safety guidelines.

\footnotetext{
1 Staff Nurse, General Hospital of Nikaias-Pireaus "Saint Panteleimon", Pireaus, Greece. email: mairitaga@hotmail.com

${ }^{2}$ Chief Nurse of P.A.C.U. at Hellenic Anticancer Institute, 'Saint Savvas' Hospital, Day Surgery Center "N. Kourkoulos”, Athens, Greece. email: mariakaprit@gmail.com.
}

Article Info: Received: June 1, 2020. Revised: June 28, 2020.

Published online: June 30, 2020. 


\section{Introduction}

Worldwide, all employees spend $1 / 3$ of their life at work. In the European Union, $10 \%$ of Health Care Professionals (HCP) is employed in hospitals. Hospitals are considered to be complex structures characterized by a wide range of industrial activities. Nursing Staff (NS) is the cornerstone of the health systems, as it has the most frequent contact with patients. This direct contact with patients makes them to be exposed to many occupational hazards, such as physical, chemical, biological, ergonomic and psychosocial factors more than other HCP [1].

Occupational exposure to pathogens is due to skin, eyes and mucous membrane with other parenteral fluids such as blood or other contaminated fluids or materials that they are likely to get in touch with. Injuries from needles and other sharp objects constitute the greatest risk for the transmission of infectious agents in HCP. The likelihood of injuries by sharp objects is much more frequent than needle sticks of the amount, while it has been found that about one in three nurses injured by needle at least once a year [2].

\section{Objectives}

Internationally, the most common injuries are those by used needles, in the attempt of NS to reposition the cover. Taking into account the statistics of USA Center Disease Control, the $32 \%$ of injuries stem from hypodermic needles, needle-suture $(19 \%)$, venipuncture using a butterfly needle $(12 \%)$, lancet $(7 \%)$, stent $(6 \%)$ and phlebotomy needles (6\%). These devices have the ability to aspirate blood, constituting the number one risk factor. Specifically, these injuries are caused during handling of the needle in the patient $(26 \%)$, in a discharge device $(23 \%)$, counter to a colleague (10\%), during cleaning trolleys and nursing premises $(10 \%)$ and when performing venipuncture (6\%). The needle stick derives during procedures in patients' wards, operating rooms, intensive care units or the emergency departments [3].

A large number of factors influence the compliance to the instructions, such as the emergent situation, the availability of appropriate equipment, the discomfort of patients, the feeling of fear, the costs of hospitalization and the ability to adapt to changes. It is noted that the compliance to guidelines is affected, through the Health Belief Model. The occupational exposure beyond the economic cost can cause fear, traumatic stress, anger, insomnia, nightmares, and depression, as well as, panic attacks during working hours to the HCP. Protecting HCP from infectious diseases is an integral part of the overall program for infections' prevention and control in every health facility $[4,5]$.

Aim of this review was to assess the degree of nurses' compliance to the guidelines of occupational exposure to pathogenic microorganisms. A specific aim of the study was the critical analysis of research data and the mapping of the main factors, which lead nurses not to follow the protective measures, while performing their duties. 


\section{Methods}

A review of literature was conducted on the Medline / PubMed, Cochrane, Scopus, and Google Scholar databases from 2000 to 2018. The keywords used in the bibliography search were, health care professionals, nurses' attitudes, occupational exposure, and safety guidelines. The inclusion criteria were: a) studies that were directly related to the topic, and b) studies in English and Greek language, published in peer-reviewed journals. The search strategy revealed 1287 studies, 1260 excluded, and finally 27 studies were appropriate for inclusion.

The identification and data extraction was performed by two reviewers. A data extraction sheet was developed with the following template: name of the first author, country of origin, year of publication, research design, aim, characteristics of participants, sample size, data collection method or instrument and, finally, the main results and outcomes. Studies' selection process is summarized in the Figure. (Flow-diagram).

\section{Results}

This review presents the main findings of 27 published studies. Five articles, with regard to hand hygiene, were found. Participants reported high compliance rates $(95 \%)$ of washing hands before and after use of gloves, whilst after the rejection of gloves, hand washing was noted to lower rates. In other studies the rate reached the $64.3 \%$. The rate of washing hands after contact with the patient appeared to be at $54 \%$ of the nurses involved. In Intensive Care Units compliance of nurses to wash hands before the beginning of the shift reached the 12\% [6-10]. In the study of Ganczak and Szych (2007), compliance to the use of gloves whenever was necessary accounted to $83 \%$, while the use of double gloves in surgeries was only $12 \%$ in the survey of Jeong and colleagues in $2008[11,12]$.

Furthermore, 9 studies showed that $50.9 \%$ of nurses repositioned the needle cap from a used syringe [13-20]. On the contrary, Stein et al. noted that $99 \%$ of nurses reported that they cover a used needle cap and $85 \%$ reject them to special equipment [7]. The results of literature review are shown in Table. 


\section{Labels of figures and tables}

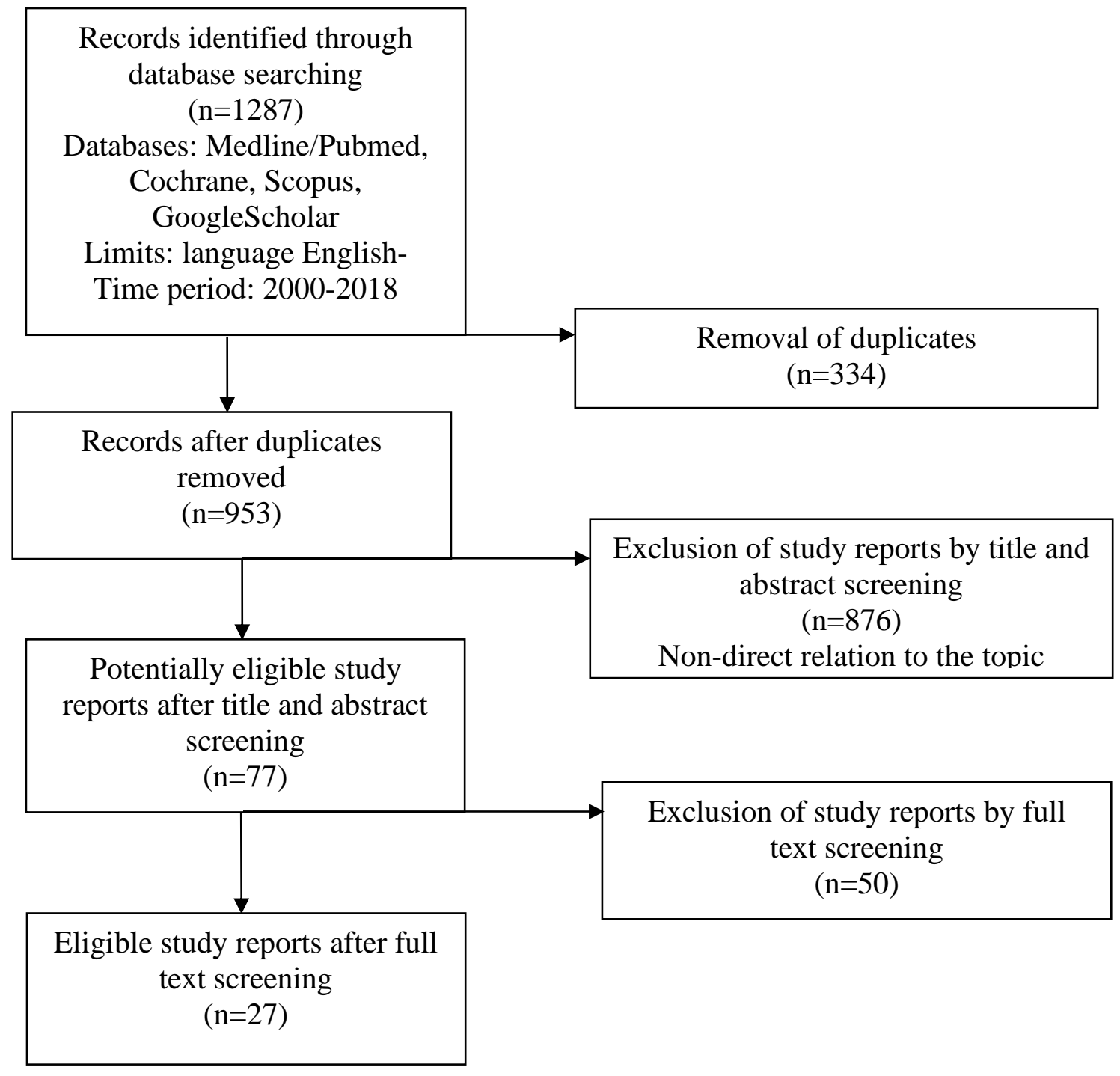

Figure 1: Flow diagram of studies selection 
Table 1: Literature Review Results

\begin{tabular}{|c|c|c|c|c|}
\hline $\begin{array}{l}\text { Authors \& Date } \\
\text { of Publications }\end{array}$ & $\begin{array}{l}\text { Participants } \\
(\mathbf{N})\end{array}$ & Study Design & Aim of Study & Results \\
\hline $\begin{array}{l}\text { Hasak et al., } \\
2018\end{array}$ & $\begin{array}{l}\text { 605 Health } \\
\text { Care Workers } \\
\text { (HCW) }\end{array}$ & $\begin{array}{l}\text { Cross-sectional } \\
\text { survey }\end{array}$ & $\begin{array}{l}\text { Assessment } \\
\text { of needle } \\
\text { stick (NS), } \\
\text { prevalence, } \\
\text { protection } \\
\text { practices and } \\
\text { attitudes }\end{array}$ & $\begin{array}{l}\text { - } 24.8 \% \text { reported } \\
\text { the injury } \\
\text { - } 25 \% \text { wore } \\
\text { double gloves }\end{array}$ \\
\hline $\begin{array}{l}\text { Suliman et al., } \\
2018\end{array}$ & $\begin{array}{l}279 \text { Student } \\
\text { Nurses }\end{array}$ & $\begin{array}{l}\text { Cross-sectional } \\
\text { and descriptive } \\
\text { study }\end{array}$ & $\begin{array}{l}\text { Prevalence } \\
\text { and risk } \\
\text { factors of NS } \\
\text { and sharp } \\
\text { injuries (SI) }\end{array}$ & $\begin{array}{l}\text { Prevalence of NS } \\
\text { and SI was } 23.7 \% \\
\text { and } 9.8 \%, \\
\text { respectively }\end{array}$ \\
\hline $\begin{array}{l}\text { Xiong et al., } \\
2017\end{array}$ & 302 Nurses & $\begin{array}{c}\text { GHQ-28 } \\
\text { Standardized } \\
\text { Questionnaire }\end{array}$ & $\begin{array}{l}\text { Investigate } \\
\text { mental } \\
\text { health status } \\
\text { of nurses } \\
\text { exposed to } \\
\text { blood through } \\
\text { NS injuries }\end{array}$ & $\begin{array}{ll}- & 162 \text { experienced } \\
\text { NI } \\
\text { - } & 75.9 \% \text { exposed } \\
\text { to blood were } \\
\text { suspected to } \\
\text { suffer from } \\
\text { mental disorder }\end{array}$ \\
\hline $\begin{array}{l}\text { d. Ettorre G., } \\
2017\end{array}$ & $\begin{array}{l}765 \text { Registered } \\
\text { Nurses (RNs) }\end{array}$ & $\begin{array}{l}\text { Cross-sectional } \\
\text { nested case- } \\
\text { control analysis }\end{array}$ & $\begin{array}{l}\text { Prevention of } \\
\text { NS and SI }\end{array}$ & $\begin{array}{l}\text { Sis were more } \\
\text { frequent among RN } \\
\text { working } 3 \text { or more } \\
\text { nightshifts }\end{array}$ \\
\hline $\begin{array}{l}\text { Kasatpibal et al., } \\
2016\end{array}$ & $\begin{array}{l}\text { 2031 Operating } \\
\text { Room Nurses } \\
\text { (ORN) }\end{array}$ & $\begin{array}{c}\text { Cross-sectional } \\
\text { study }\end{array}$ & $\begin{array}{c}\text { Prevalence } \\
\text { and risk } \\
\text { factors of NS } \\
\text { and SI }\end{array}$ & $\begin{array}{l}\text { Prevalence of Nis } \\
\text { and Sis were } 23.7 \% \\
\text { and } 9.8 \% \text {, } \\
\text { respectively }\end{array}$ \\
\hline $\begin{array}{l}\text { Zhang et al., } \\
2015\end{array}$ & 463 Nurses & Questionnaire & $\begin{array}{c}\text { Report the } \\
\text { prevalence } \\
\text { and risk } \\
\text { factors of NSs }\end{array}$ & $\begin{array}{l}64.9 \% \text { reported } \\
\text { the injury } \\
\text { - NSs more } \\
\text { common among } \\
\text { female and } \\
\text { young Nurses } \\
\end{array}$ \\
\hline Azadi et al., 2011 & $\begin{array}{l}111 \text { Clinical } \\
\text { Nurses }\end{array}$ & $\begin{array}{c}\text { Cross-sectional } \\
\text { study }\end{array}$ & $\begin{array}{l}\text { Determine the } \\
\text { frequency of } \\
\text { NSs }\end{array}$ & $\begin{array}{l}\text { - } 54.1 \% \text { had no } \\
\text { experience of } \\
\text { contaminated } \\
\text { injuries } \\
\text { - } 36.8 \% \text { reported } \\
\text { the injury }\end{array}$ \\
\hline
\end{tabular}




\begin{tabular}{|c|c|c|c|c|}
\hline $\begin{array}{l}\text { Efstathiou et al., } \\
2011\end{array}$ & $\begin{array}{l}4 \text { focus groups } \\
\text { of Nurses } \\
\text { (N=30 each } \\
\text { group) }\end{array}$ & $\begin{array}{c}\text { Qualitive research } \\
\text { design }\end{array}$ & $\begin{array}{l}\text { Elicit Nurses' } \\
\text { perception of } \\
\text { the factors } \\
\text { influencing } \\
\text { compliance } \\
\text { with Standard } \\
\text { Precautions } \\
\text { (SP) }\end{array}$ & $\begin{array}{ll}\text { - } & \text { Emergency } \\
\text { situation } \\
\text { - } & \text { Lack of } \\
\text { protective } \\
\text { equipment } \\
\text { available } \\
\text { - Patients' } \\
\text { discomfort }\end{array}$ \\
\hline $\begin{array}{l}\text { Nagao et al., } \\
2009\end{array}$ & $\begin{array}{c}164 \text { Staff } \\
\text { Nurses (SN) }\end{array}$ & $\begin{array}{l}\text { Retrospective } \\
\text { study }\end{array}$ & $\begin{array}{c}\text { Barrier } \\
\text { precautions }\end{array}$ & $\begin{array}{l}15.41 \% \text { Scrub } \\
\text { Nurses injured } \\
\text { during "counting } \\
\text { and shorting of } \\
\text { sharps" }\end{array}$ \\
\hline $\begin{array}{l}\text { Delobelle et al., } \\
2009\end{array}$ & $\begin{array}{l}71 \text { Primary } \\
\text { HCW } \\
69 \text { Nurses }\end{array}$ & $\begin{array}{ll}\text { - } & \text { Cross- } \\
\text { sectional } \\
\text { study } \\
\text { - } & \text { Questionnaire }\end{array}$ & $\begin{array}{l}\text { Exploration } \\
\text { HIV/ AIDS- } \\
\text { related } \\
\text { knowledge, } \\
\text { attitudes, } \\
\text { practices and } \\
\text { perceptions }\end{array}$ & $\begin{array}{l}3 \text { out of } 4 \text { Nurses } \\
\text { practiced Universal } \\
\text { Practices (UP) }\end{array}$ \\
\hline Zafar et al., 2008 & $\begin{array}{l}29 \text { Doctors } \\
51 \text { Nurses }\end{array}$ & $\begin{array}{ll}\text { - } & \text { Cross- } \\
\text { sectional } \\
\text { study } \\
\text { - } \\
\text { Structured } \\
\text { pre- tested } \\
\text { Questionnaire }\end{array}$ & $\begin{array}{l}\text { Assessment } \\
\text { the } \\
\text { knowledge, } \\
\text { attitude and } \\
\text { practices } \\
\text { regarding NSs }\end{array}$ & $\begin{array}{l}-45 \% \text { NSs } \\
\text { - } \quad \text { Injury frequency } \\
\text { higher among } \\
\text { doctors } \\
(\mathrm{p}<0.001)\end{array}$ \\
\hline $\begin{array}{l}\text { Paudyal et al., } \\
2008\end{array}$ & $324 \mathrm{HCW}$ & $\begin{array}{l}\text { Questionnaire } \\
\text { Survey }\end{array}$ & $\begin{array}{l}\text { Assessment } \\
\text { the } \\
\text { knowledge, } \\
\text { attitude and } \\
\text { infection } \\
\text { control } \\
\text { practices }\end{array}$ & $\begin{array}{l}\text { Maximum scores of } \\
\text { knowledge, attitude } \\
\text { and practice items } \\
\text { were } 16 \%, 14 \% \text { and } \\
0.3 \% \text {, respectively }\end{array}$ \\
\hline Jeong et al., 2008 & $\begin{array}{l}\text { 158 Operating } \\
\text { Room Scrub } \\
\text { Nurses }\end{array}$ & $\begin{array}{ll} & \text { Cross- } \\
\text { sectional } \\
\text { study } \\
\text { - } \\
\text { Self- } \\
\text { administered } \\
\text { Questionnaire }\end{array}$ & $\begin{array}{l}\text { Determine the } \\
\text { level of } \\
\text { compliance } \\
\text { with /and } \\
\text { education on } \\
\text { standard } \\
\text { precautions }\end{array}$ & $\begin{array}{ll} & 12 \% \text { double } \\
\text { gloving } \\
\text { - } \% \text { protective } \\
\text { eyewear } \\
10 \% \text { not } \\
\text { recapping used } \\
\text { needles }\end{array}$ \\
\hline $\begin{array}{l}\text { Ganczak and } \\
\text { Szych, } 2007\end{array}$ & $\begin{array}{l}601 \text { Surgical } \\
\text { Nurses }\end{array}$ & $\begin{array}{c}\text { Confidential } \\
\text { Questionnaire }\end{array}$ & $\begin{array}{l}\text { Evaluation of } \\
\text { compliance } \\
\text { with personal }\end{array}$ & $\begin{array}{l}\text { - } 83 \% \text { glove use } \\
\text { - } 9 \% \text { protective } \\
\text { eyewear }\end{array}$ \\
\hline
\end{tabular}




\begin{tabular}{|c|c|c|c|c|}
\hline & & & $\begin{array}{l}\text { protective } \\
\text { equipment }\end{array}$ & \\
\hline $\begin{array}{c}\text { Schmid et al., } \\
2007\end{array}$ & $\begin{array}{l}787 \text { Employees } \\
\text { and Medical } \\
\text { students }\end{array}$ & Questionnaire & $\begin{array}{l}\text { Obtain data } \\
\text { for incidence, } \\
\text { reporting and } \\
\text { follow-up of } \\
\text { occupational } \\
\text { exposure to } \\
\text { blood or other } \\
\text { body fluids }\end{array}$ & $\begin{array}{ll}\text { - } & 29.5 \% \text { students } \\
& \mathrm{NS} \\
\text { - } & 22.5 \% \\
& \text { Employees NS }\end{array}$ \\
\hline Golan et al., 2006 & $\begin{array}{l}1619 \text { Hand } \\
\text { hygiene } \\
\text { opportunities }\end{array}$ & Crossover trial & $\begin{array}{c}\text { Hand hygiene } \\
\text { compliance }\end{array}$ & $\begin{array}{l}\text { Compliance was } \\
10 \% \text { before care was } \\
\text { given and } 36 \% \text { after } \\
\text { one }\end{array}$ \\
\hline $\begin{array}{c}\text { Ayaranci and } \\
\text { Kosgeroglu, } 2004\end{array}$ & 139 Nurses & Questionnaire & $\begin{array}{l}\text { Determination } \\
\text { the rate of } \\
\text { blood borne } \\
\text { infections } \\
\text { after NS and } \\
\text { SI }\end{array}$ & $\begin{array}{l}69.1 \% \text { not } \\
\text { reported the } \\
\text { injury } \\
\text { - } 32.4 \% \text { not } \\
\text { vaccinated } \\
\text { against Hepatitis } \\
\text { B virus } \\
\end{array}$ \\
\hline $\begin{array}{l}\text { Blegen et al., } \\
2004\end{array}$ & $1105 \mathrm{SN}$ & Questionnaire & $\begin{array}{l}\text { Assure the } \\
\text { quality of } \\
\text { patient care }\end{array}$ & $\begin{array}{ll}- & 48 \% \text { NS } \\
\text { - } & 22 \% \text { other } \\
\text { exposures to } \\
\text { body fluids }\end{array}$ \\
\hline $\begin{array}{c}\text { Bennet and } \\
\text { Mansell, } 2004\end{array}$ & $\begin{array}{c}379 \\
\text { Community } \\
\text { Nurses }\end{array}$ & $\begin{array}{c}\text { Questionnaire } \\
\text { survey }\end{array}$ & $\begin{array}{l}\text { Compliance } \\
\text { with UP }\end{array}$ & $\begin{array}{ll}- & 21 \% \mathrm{NS} \\
- & 84 \% \text { reported the } \\
& \text { injury } \\
\end{array}$ \\
\hline Osborne, 2003 & 227 ORN & $\begin{array}{l}\text { - } \begin{array}{l}\text { Descriptive } \\
\text { correlation } \\
\text { study }\end{array} \\
\text { - } \\
\text { Questionnaire }\end{array}$ & $\begin{array}{l}\text { Compliance } \\
\text { with } \\
\text { occupational } \\
\text { exposures }\end{array}$ & $\begin{array}{ll}\text { - } & 55.6 \% \text { double } \\
\text { gloving } \\
\text { 92\% eye } \\
\text { protection } \\
\end{array}$ \\
\hline Wnut, 2003 & $28 \mathrm{HCW}$ & $\begin{array}{c}\text { Observational } \\
\text { study }\end{array}$ & $\begin{array}{l}\text { Determine the } \\
\text { epidemiology } \\
\text { of } \\
\text { occupational } \\
\text { exposure to } \\
\text { HIV infection }\end{array}$ & $\begin{array}{l}\text { Nurses are most at } \\
\text { risk for occupational } \\
\text { exposure }\end{array}$ \\
\hline Stein et al., 2003 & $\begin{array}{l}143 \text { Nurses } \\
75 \text { Doctors }\end{array}$ & $\begin{array}{l}\text { Cross- sectional } \\
\text { survey }\end{array}$ & $\begin{array}{l}\text { Compliance } \\
\text { with UP }\end{array}$ & $\begin{array}{l}\text { Significant } \\
\text { differences } \\
\text { concerning } \\
\text { transmission and } \\
\text { risks }(\mathrm{p}<0.001)\end{array}$ \\
\hline
\end{tabular}




\begin{tabular}{|c|c|c|c|c|}
\hline $\begin{array}{l}\text { Doebbeling et al., } \\
2003\end{array}$ & $3223 \mathrm{HCW}$ & $\begin{array}{l}\text { Assessment of } \\
\text { occupational risk } \\
\text { factors }\end{array}$ & $\begin{array}{l}\text { Examination } \\
\text { of factors } \\
\text { associated } \\
\text { with blood } \\
\text { exposure }\end{array}$ & $\begin{array}{l}\text { Increased } 2 \%-3 \% \\
\text { for each sharp } \\
\text { handled in a typical } \\
\text { week }\end{array}$ \\
\hline Chan et al., 2002 & 306 Nurses & $\begin{array}{l}\text { Cross- sectional } \\
\text { survey }\end{array}$ & $\begin{array}{l}\text { Knowledge } \\
\text { and } \\
\text { compliance } \\
\text { with UP }\end{array}$ & $\begin{array}{l}\text { Inadequate } \\
\text { knowledge UP } \\
\text { insufficient and } \\
\text { inappropriate }\end{array}$ \\
\hline Naing et al., 2001 & $150 \mathrm{SN}$ & $\begin{array}{l}\text { Structured self- } \\
\text { administered } \\
\text { Questionnaire }\end{array}$ & $\begin{array}{c}\text { Identification } \\
\text { of compliance } \\
\text { of glove } \\
\text { utilization }\end{array}$ & $\begin{array}{l}\text { Low compliance } \\
(13.5 \%)\end{array}$ \\
\hline $\begin{array}{l}\text { Godin et al., } \\
2000\end{array}$ & $156 \mathrm{RN}$ & $\begin{array}{l}\text { Self-administered } \\
\text { Questionnaire }\end{array}$ & $\begin{array}{l}\text { Prediction } \\
\text { and } \\
\text { explanation } \\
\text { nurses' } \\
\text { adherence } \\
\text { to UP }\end{array}$ & $38 \%$ applied the UP \\
\hline Shiao et al., 1999 & $10469 \mathrm{HCW}$ & Questionnaire & $\begin{array}{l}\text { Identification } \\
\text { of factors } \\
\text { associated } \\
\text { with non- } \\
\text { reporting } \\
\text { behavior of } \\
\text { Sis }\end{array}$ & $\begin{array}{l}\text { - } 87.3 \% \\
\text { experience with } \\
\text { Sis } \\
\text { - } 81.2 \% \text { Sis not } \\
\text { reported }\end{array}$ \\
\hline
\end{tabular}

\section{Discussion}

Through this review of literature, studies show that an emergency situation could be a significant barrier to compliance to necessary procedures. The lack of protective equipment (gloves, masks etc) and the multiple responsibilities of the nurses could be a major obstacle to obtain the necessary precautions [28].

In contrast to the above, the daily implementation of the precautions removes the stress of a possible infection. In many studies, participants, also, reported, that it should be motivations, which will drive to the use of precautionary measures [2729]. These are the high-risk group of patients, the negative experience nurses could have after exposure to pathogens, continuous information on new techniques and reminder (with signs, posters, etc.), caring foreign patients from underdeveloped countries and the good example that can provide the high-ranking colleagues [3031].

It is clear that nurses come in contact with many occupational hazards, daily. Often having as a priority the health and safety of patient neglect to ensure their own security through non-compliance to guidelines for protecting themselves [32]. 
Hematogenous transmission of diseases often occurs after injury and may cause contamination of the nurse. The most common risks is the virus of human immunodeficiency (HIV) and hepatitis B or hepatitis C, but there are more than 20 blood diseases which may infect nurses [6]. Injuries from needles and other sharp objects are responsible for the transmission of infectious agents in the healthcare. Nurses have the highest rates in this type of injury than other health professionals [17].The observed high occupational exposure to pathogens among nurses could be attributed, among others, to the failure of observing safety precautions. The guidelines for nurse prophylaxis, generally, define measures concerning the organization of monitoring infections associated with health care facilities, health staff assessment on the state of vaccination, staff training in infection control and special measures for protection from blood- transmitted diseases such as the use of gloves (e.g., vaccination against hepatitis B) [14].

Last but not least, the most important measure is the prevention of these injuries. So it is necessary, nurses avoid coverage of used needles, because this is a common movement, which causes of self-harm [24]. The contaminated sharp instruments must be disposed of in a special container, never on the patient or in areas that may be covered with soft materials such as gauze or paper [25]. It is also important to avoid delivering sharp instruments from hand to hand. Avoiding accidents contribute continuous updating of nurses with clear instructions or warnings [25].

\section{Study Limitations}

Although there are numerous studies addressing the issue of nurses' compliance to the guidelines and management of them, there are several limitations. Those include the study design, the observation period and the sample size.

\section{Clinical Implications}

In clinical practice it is important to make changes in education, which will improve the prevention of such incidents. More specifically, the presence of health professional in primary and secondary health care systems is essential for ensuring communication between health providers and NS.

\section{Research Directions}

The data indicate that nurses derive their knowledge from a large extent on previous experience, including the experience of colleagues. Also, it is noted that during nursing education is necessary to prepare trainees to work in different situations. The well-trained nurses in combination with their experiences in patient's care could approach, manage and deal with them using a standard model nursing care.

\section{Conclusions}

The implementation of appropriate guidelines provides the necessary technical equipment and preserves 35-40 million HCP worldwide, away from the transmission of pathogenic microorganisms. 


\section{References}

[1] L. Kostun \& D. Goldsmith, Needlesticks and nonreporting: A review of blood borne pathogen exposure among health care workers, Epidemiology 22(1), 2011, 253- 254.

[2] S. Keller, K. Daley, J. Hyde, R.S. Greif, D.R. Church, Hepatitis C prevention with nurses, Nursing and Health Sciences, 7, (2005), 99-106.

[3] N. Tabak, A.M. Shiaabana, S. Shasha, The health beliefs of hospital staff and the reporting of needle stick injury, J.Clin.Nurs., 15, (2006), 1228-39.

[4] S. Pournaras, A. Tsakris, K. Mandraveli, A. Faitatzidou, J. Douboyas, A. Tourkantonis, Reported needlestick and sharp injuries among health care workers in a Greek general hospital, Occupational Medicine, 49, (1999), 423426.

[5] P. Cervini \& C. Bell, Brief Report: Needle stick injury and Inadequate PostExposure practice in Medical Students, J. Gen. Intern. Med., 20, (2005), 419421.

[6] L. Naing, R. Nordin \& R. Musa, The prevalence of, and factors related to, compliance with glove utilization among nurses in Hospital Universiti Sains Malaysia, The Southeast Asian Journal of Tropical Medicine and Public Health, 32(3), (2001), 636-642.

[7] A.D. Stein, T.P. Makarawo \& M.F. Ahmad, A survey of doctors' and nurses' knowledge, attitudes and compliance with infection control guidelines in Birmingham teaching hospitals, The Journal of Hospital Infection, 54(1), (2003), 68-73.

[8] R. Chan, A. Molassiotis, E. Chan, V. Chan, B. Ho, C.Y. Lai, P. Lam, F. Shit $\&$ I. Yiu, Nurses' knowledge of and compliance with universal precautions in an acute care hospital, International Journal of Nursing Studies, 39(2), (2002), 157- 163.

[9] B.N. Doebbeling, T.E. Vaughn, K.D. McCoy, S.E. Beekmann, R.F. Woolson, K.J. Ferguson \& J.C. Torner, Percutaneous injury, blood exposure, and adherence to standard precautions: are hospital-based health care providers still at risk?, Clinical Infectious Diseases: an Official Publication of the Infectious Diseases Society of America, 37(8), (2003), 1006-1013.

[10] Y. Golan, S. Doron, J. Griffith, H. El Gamal, M. Tanios, K. Blunt, et al., The impact of gown-use requirement on hand hygiene compliance, Clinical Infectious Diseases : an Official Publication of the Infectious Diseases Society of America, 42(3), (2006), 370-376.

[11] M. Ganczak \& Z. Szych, Surgical nurses and compliance with personal protective equipment, The Journal of Hospital Infection, 66(4), (2007), 346351.

[12] I. Jeong, J. Cho \& S. Park, Compliance with standard precautions among operating room nurses in South Korea, American Journal of Infection Control, 36(10), (2008), 739-742. 
[13] A. Wnuk, Occupational exposure to HIV infection in health care workers, Med Sci Monit,. 9(5), (2003), 197-200.

[14] H. Drexler, K. Schmid \& C. Schwager, Needle-stick injuries and other occupations exposures to body fluids amongst employees and medical students of a German university: Incidence and follow-up, Journal of Hospital Infection, 67, (2007), 124-130.

[15] M. Suliman, M. Qadire , M. Alazzam, S. Aloush, A. Alsaraireh, F.A. Alsaraireh, Students nurses' knowledge and prevalence of Needle Stick Injury in Jordan, Nurse Educ Today., 60, (2017), 23-27.

[16] N. Kasatpibal, J.D. Whitney, S. Katechanok, S. Ngamsakulrat, B. Malairungsakul, P. Sirikulsathean, et al., Prevalence and risk factors of needlestick injuries, sharps injuries, and blood and body fluid exposures among operating room nurses in Thailand, Am. J. Infect. Control. 44, (2016), 85-90.

[17] X. Xiong, M. Li, Y. Jiang, X. Tong, Y. Peng, Study of blood exposure-related mental health illness among clinical nurses, Front. Med., 11, (2017), 147-151.

[18] S. Osborne, Influences on compliance with standard precautions among operating room nurses. American Journal of Infection Control 31(7), 4(2003), $15-423$.

[19] G. Bennett \& I. Mansell, Universal precautions: a survey of community nurses' experience and practice, Journal of Clinical Nursing, 13(4), (2004), 413-421.

[20] G. Godin, H. Naccache, S. Morel \& M.F. Ebacher, Determinants of nurses adherence to universal precautions for venipunctures, American Journal of Infection Control, 28(5), (2000), 359-364.

[21] P. Delobelle, J.L. Rawlinson, S. Ntuli, I. Malatsi, R. Decock \& A.M. Depoorter, HIV/AIDS knowledge, attitudes, practices and perceptions of rural nurses in South Africa, Journal of Advanced Nursing, 65(5), (2009), 1061-1073.

[22] A. Zafar, N. Aslam, N. Nasir, R. Meraj \& V. Mehraj, Knowledge, attitudes and practices of health care workers regarding needle stick injuries at a tertiary care hospital in Pakistan, The Journal of the Pakistan Medical Association, 58(2), (2008), 57-60.

[23] P. Paudyal, P. Simkhada \& J. Bruce, Infection control knowledge, attitude, and practice among Nepalese health care workers, American Journal of Infection Control, 36(8), (2008), 595-597.

[24] G. Efstathiou, E. Papastavrou, V. Raftopoulos, A. Merkouris, "Factors influencing nurses" compliance with Standard Precautions in order to avoid occupational exposure to microorganisms: A focus group study, BMC Nurs., 10, (2011), 1.

[25] J.S. Shiao, M.L. McLaws, K.Y. Huang, W.C. Ko \& Y.L. Guo, Prevalence of nonreporting behavior of sharps injuries in Taiwanese health care workers, American Journal of Infection Control, 27(3), (1999), 254-257.

[26] U. Ayranci, \& N. Kosgeroglu, Needlestick and sharps injuries among nurses in the healthcare sector in a city of western Turkey, The Journal of Hospital Infection, 58(3), (2004), 216-223. 
[27] M.A. Blegen, T. Vaughn, G. Pepper, C. Vojir, K. Stratton, M. Boyd \& G. Armstrong, Patient and staff safety: voluntary reporting, The official Journal of the American college of Medical Quality, 19(2), (2004), 67-74.

[28] J.M. Hasak, C.B. Novak, J.M.M. Patterson, S.E. Mackinnon, Prevalence of Needlestick Injuries, Attitude Changes, and Prevention Practices Over 12 Years in an Urban Academic Hospital Surgery Department, Ann Surg., 267(2), (2018), 291-296.

[29] M. Nagao, Y. Iinuma, J. Igawa, Y. Matsumura, M. Shirano, A. Matsushima, et al., Accidental exposures to blood and body fluid in the operation room and the issue of underreporting, American Journal of Infection Control, 37(7), (2009), 541-544.

[30] A. Azadi, M. Anoosheh \& A. Delpisheh, Frequency and barriers of underreported needlestick injuries amongst Iranian nurses, a questionnaire survey, Journal of Clinical Nursing, 20(3-4), (2011), 488-493.

[31] G. d'Ettorre, Needlestick and Sharp Injuries Among Registered Nurses: A Case-Control Study, Ann Work Expo Health, 61(5), (2017), 596-599.

[32] X. Zhang, Y. Gu, M. Cui, L. Stallones, H. Xiang, Needlestick and sharps injuries among nurses at a teaching hospital in China, Workplace Health \& Safety, 63(5), (2015), 219-225. 